\title{
Academic dishonesty in stricto sensu postgraduate programs in accounting
}

\author{
Regina Cardoso Fróes ${ }^{1,2}$ \\ (D) https://orcid.org/0000-0002-2871-5484 \\ Email: regina.froes@unimontes.br \\ Denise Mendes da Silva ${ }^{1}$ \\ (D) https://orcid.org/0000-0002-1490-5148 \\ Email: denise.mendes@ufu.br
}

${ }^{1}$ Universidade Federal de Uberlândia, Faculdade de Ciências Contábeis, Uberlândia, MG, Brazil
${ }^{2}$ Universidade Estadual de Montes Claros, Centro de Ciências Sociais e Aplicadas, Departamento de Ciências Contábeis, Montes Claros, MG,
Brazil

Received on 09.28.2020 - Desk acceptance on 10.19.2020 - $2^{\text {nd }}$ version approved on 05.20.2021

Editor-in-Chief: Fábio Frezatti

Associate Editor: Jacqueline Veneroso Alves da Cunha

\begin{abstract}
The aim of this article was to analyze academic dishonesty in stricto sensu postgraduate courses in accounting from the perspective of students, teachers, and teaching institutions. There is a gap in the research on academic dishonesty in stricto sensu postgraduate programs in accounting, especially from the analysis perspective of this study, which considers hypothetical situations classified into five categories of dishonesty: fraud/cheating, helping other students, plagiarism, fabricating information, and self-plagiarism/similarities. The study is important due to the role of stricto sensu postgraduate courses not only in training professionals who work or will work in public and private institutions, but also and primarily in training teachers and researchers. Dishonest behaviors can influence the professional lives of those involved, who are predominantly motivated by opportunistic interests that cause damage to the image of professionals in the area and to society. The data were collected through applying two questionnaires adapted from the studies of Braun and Stallworth (2009) and Oliveira and Chacarolli (2013). Mann-Whitney $U$ and Wilcoxon statistical tests were used to analyze the data. The findings indicated the existence of an expectations gap between teachers and students regarding academic dishonesty in stricto sensu postgraduate programs in accounting. The significant differences found in perceptions regarding cases of dishonesty underline the difficulty for students and teachers to evaluate what is dishonest or not in situations of fraud/cheating and helping other students to engage in academic dishonesty. The differences in students' and teachers' perceptions may occur due to a lack of clear rules in the teaching institutions. Therefore, universities could undertake actions to address/prevent dishonest behaviors by establishing internal regulations and promoting discussions involving the whole academic community.
\end{abstract}

Keywords: academic dishonesty, penalties, stricto sensu postgraduate programs, accounting. 


\section{INTRODUCTION}

Within the academic environment, the concept of dishonesty is primarily associated with cheating (Blankenship \& Whitley, 2000; McCabe \& Trevino, 1993; Nasu \& Afonso, 2020; Simon et al., 2004; Von Dran et al., 2001). Moreover, McCabe and Trevino (1993) relate academic dishonesty with plagiarism, which, according to Pavela (1997), is the intentional or conscious use of someone else's words or ideas as one's own in some academic exercise. Academic dishonesty is also associated with fraud (Bujaki et al., 2019; Kisamore et al., 2007; Lambert et al., 2003), which is described as "deception; sharp practice; deceit; cheating; trickery; falsification" (Bueno, 2007, p. 370).

Internationally, the studies on academic dishonesty have been developed in undergraduate courses in the areas of business, including accounting (Braun \& Stallworth, 2009; Bujaki et al., 2019; Johns \& Strand, 2000; Kisamore et al., 2007), chemistry (Simon et al., 2004), and others (Lambert et al., 2003). In Brazil, studies on the theme are found in undergraduate courses in the areas of law, management, pedagogy, engineering (Pimenta, 2010), health (Sousa et al., 2016), accounting, and business (Avelino \& Lima, 2017; Oliveira \& Chacarolli, 2013; Oliveira et al., 2014; Santos et al., 2020).

Unlike the aforementioned authors, Veludo-de-Oliveira et al. (2014) also included lato sensu postgraduate students from the area of business in their research conducted in Brazil. With regards to lato sensu postgraduate courses in the area of accounting, Nasu and Afonso (2020) analyzed the relationship between cynicism and expectations of cheating in academic and professional life, based on the participation of 92 students.

Ferreira et al. (2013), in turn, researched the occurrence of plagiarism in stricto sensu postgraduate courses at the University of São Paulo (USP) in an exploratory way and concluded that students plagiarize with the aim of achieving better academic performance. This research involved postgraduate students from all areas; however, the researchers only evaluated the perception of students regarding plagiarism as a form of academic dishonesty. The study by Andrade (2011) also addressed the theme of academic dishonesty in the context of stricto sensu postgraduate studies. The author evaluated the attitudes of accounting researchers (master's graduates, master's students, doctoral students, and experienced researchers) in relation to misconduct in scientific research and identified the frequency of its occurrence and the intensity of the factors that influence it.

In light of the above, it can be observed that the studies involving academic dishonesty in the area of accounting have focused more on undergraduate courses, identifying students' and teachers' perceptions regarding the subject, even with respect to penalties and, in some studies, seeking to identify the motivations for dishonest practices in the academic environment. The studies have also failed to distinguish between types or categories of academically dishonest behaviors, nor have they carried out any assessment of the procedural documents of the teaching institutions to ascertain if and how academic dishonesty is addressed.

Therefore, this study aims to fill a gap in the research by investigating, in stricto sensu postgraduate courses in accounting, students' and teachers' perceptions with respect to academic dishonesty, which is classified into five categories, using the hypothetical situations of: 1) fraud/cheating; 2) helping other students to engage in academic dishonesty; 3) plagiarism; 4) fabricating information, references, or results; and 5) self-plagiarism and similarities in studies. Moreover, students' and teachers' perceptions are analyzed with regards to the applicable penalties for dishonest behavior, and these perceptions are complemented with an analysis of the statutes, regulations, and disciplinary codes of the teaching institutions regarding their postgraduate programs, in search of rules of conduct and punishments for cases of dishonesty.

Within this context, the following problematization is used to guide this study: what is the perception of students and teachers and what is the position of teaching institutions regarding academic dishonesty in stricto sensu postgraduate courses in accounting? The aim of the study is to analyze academic dishonesty in stricto sensu postgraduate courses in accounting from the perspective of students, teachers, and teaching institutions.

According to Simon et al. (2004), discussion and studies about academic dishonesty are important due to the potential risk it poses to the academic process and to research, particularly because, as the results of the study by Veludo-de-Oliveira et al. (2014) suggest, students who have already been involved in situations of dishonesty at school are unrestricted from getting involved in them again, which represents a risk to professional conduct. Therefore, studies on academic dishonesty at the stricto 
sensu postgraduate studies level are important, as the students in these courses are or could go on to be teachers, and the current teachers of the programs are responsible for helping in the ethical training of the students.

There are expected to be differences between students' and teachers' perceptions regarding dishonest behaviors; however, where there are different perceptions, an "expectations gap" will be detected between the two groups. With this, it is understood that discussions regarding academic dishonesty should be encouraged in the area of stricto sensu postgraduate programs in accounting, given that accountants are expected to adopt an ethical attitude toward the professional questions they will encounter, whether in teaching or working in private or public institutions.

Besides academic dishonesty, authors such as Braun and Stallworth (2009), Kisamore et al. (2007), Lambert et al. (2003), McCabe and Trevino (1993), Oliveira and Chacarolli (2013), Oliveira et al. (2014), Pavela (1997), Simon et al. (2004), and Sousa et al. (2016) discuss the applicable penalties for behaviors that are considered to be dishonest and the motivations behind such behaviors. In addition, it is important to analyze the procedural documents of the teaching institutions concerning their stricto sensu postgraduate programs in accounting in order to identify each one's position with respect to academic dishonesty, as differences in perceptions between students and teachers may occur due to a lack of clear rules regarding behaviors that are considered to be academically dishonest and the applicable penalties.
The main contribution of the study is it offers a triangulation in the analysis of academic dishonesty from the perspective of students, teachers, and teaching institutions. Based on the results, universities could undertake actions to address/prevent dishonest behaviors in the personal and institutional environments, by establishing internal regulations and promoting discussions involving the whole academic community. As McCabe and Trevino (1993) state, the adoption of behaviors to reduce academic dishonesty is not limited to the use of codes and rules, but also requires everyone to be included in building common policies.

The existence of clear rules regarding academic dishonesty and penalties in stricto sensu postgraduate programs demonstrates a proactive action that helps the teaching staff to solve problems, without transferring this responsibility to the teachers of the disciplines. For McCabe (2005), no institution develops a policy for preventing engagement in academic dishonesty without using proactive strategies and strategies to convince people of the importance of academic integrity.

This study also seeks to innovate in relation to previous ones by contributing to the literature by categorizing five types of academic dishonesty. The four categories proposed by Pavela (1997) - 1) fraud/cheating; helping other students to engage in academic dishonesty; 3 ) plagiarism; 4) fabricating information, references, or results - were complemented with one category reported by Diniz $(2015,2018)$ and Frezatti (2018): self-plagiarism and similarities in studies.

\section{LITERATURE REVIEW}

\subsection{Academic Dishonesty}

According to Pavela (1997), academic dishonesty is an offense that undermines bonds of trust and honesty between members of the academic community and frustrates those who depend on knowledge and integrity. McCabe and Trevino (1993) highlight that institutions should distinguish between appropriate and inappropriate behavior. Lambert et al. (2003), in turn, associate academic dishonesty with the concept of fraud, stating that it is an affront to higher education, to honest students, to teaching staff, and to the institution.

According to Kisamore et al. (2007), research on dishonesty in universities has increased as a result of academic and corporate scandals. From this perspective, it is possible to identify, both abroad and in Brazil, cases of corporate fraud such as that of Enron (Murcia, 2005; Sanchez \& Innarelli, 2012; Veludo-de-Oliveira et al., 2014), WorldCom (Murcia, 2005; Veludo-de-Oliveira et al., 2014), Tyco International (Veludo-de-Oliveira et al., 2014), Parmalat, and Bombril (Murcia, 2005), in which information was manipulated, adversely affecting shareholders, employees, and society.

The study by Veludo-de-Oliveira et al. (2014) indicated a relationship between engagement in academic dishonesty reported by students and their intentions to engage in fraud. The result suggests that students who have already been involved in situations of dishonesty at school are unrestricted from getting involved in them again. This is worrying, as it may represent the possibility of future involvement in fraud in the corporate environment (Veludo-de-Oliveira et al., 2014). 
The aforementioned cases and, more recently in Brazil, the corruption scandal at Petrobras suggest a deterioration in ethical standards in the corporate workplace. The fact is that, in many situations, the acceptance of dishonest behaviors did not begin in the work environment, but rather in other contexts of the individual's life, such as the academic one. Bujaki et al. (2019) highlight that the consequences of academic fraud may be just as damaging as those of any commercial fraud, given that academic fraud can compromise the integrity of an academic institution, reduce the value of the students' diplomas, and erode the public's trust in academia.

According to Sanchez and Innarelli (2012), academic dishonesty is defined as fraud, plagiarism, outside help, and electronic fraud. For Kisamore et al. (2007), academic dishonesty involves a construct that, besides cheating and fraud, encompasses other forms of academic deceipt, such as plagarism and inadequate collaboration. According to Pimenta (2010), plagiarism corresponds to copying texts and work, such as projects, reports, end-of-course papers, and dissertations, among others, without referencing the author.

For Silva (2008), there are three classifications for plagiarism: total, when the whole text is used without citing the source; partial, when sentences or paragraphs from different sources are used; and conceptual, when someone else's ideas, concepts, or theory are used as if they were the author's own. Along this same line, Sanchez and Innarelli (2012) point out that academia recognizes various types of plagiarism, such as: self-plagiarism, when the author uses their own text, as a new edition, without referencing their previous paper; ghost authorship, which is the inclusion of authors who did not actually contribute to the study; literary plagiarism, when texts are used by substituting words; and content plagiarism, that is, the use of the original author's ideas without giving them due credit.

Sanchez and Innarelli (2012) add that plagiarism has evolved due to the advancement of computational capacity, enabling access to previously restricted content, as well as greater mastery of technology by students, which enhances its use. Therefore, control by teachers in higher education institutions (HEIs), by evaluators in research support agencies, and by editors of scientific journals has also tended to evolve, with them using online resources, search engines, and other plagiarism detection software, all of which are resources mentioned by Bujaki et al. (2019).
According to Diniz (2015), although there are still cases of plagiarized papers being submitted to journals, they are occurring less often, and cases of self-plagiarism are more common. Regarding self-plagiarism, Frezatti (2018) believes that the situation requires a more detailed and careful approach, as the claim that self-plagiarism does not harm others oversimplifies the problem. Diniz (2018) supports this understanding; however, for situations where no publication occurred, such as participations in conferences, and where there was no cession of rights, many journals reveal a degree of similarity and understand that previously published versions are merely stages of an article.

According to Diniz (2018), the situation becomes more complicated when there was publication in journals, as a contract was signed ceding rights. In these cases, the journal needs to intervene by analyzing the new publication so that the author rewrites the sections where there is similarity. For Diniz (2018), some authors have difficulty understanding and separating "authorship" from "ownership" of an intellectual piece of work and get offended. It is necessary to understand that, from the moment they sign a contract ceding rights to the original publisher, the problem leaves the field of ethics and becomes a commercial law problem (Diniz, 2018).

Diniz (2015) warns that, despite investments by publishers in plagiarism detectors, the hardest case to observe using similarities verification systems is plagiarism of ideas. In some cases, experience and attention are required of the journal reviewer to perceive the similarities in the ideas contained in the articles or in different languages (Diniz, 2018). Frezatti (2018) highlights that the research environment could be improved if plagiarism were treated more in the moral sense than in the legal one. The aforementioned author understands that it is possible to change the environment and invites the scientific community to make a collective commitment, each one in their own space, for change to occur.

This study uses the categorization identified by Pavela (1997) to group the academically dishonest behaviors described by McCabe and Trevino (1993) and Sousa et al. (2016), adding one more category: self-plagiarism and similarities in studies, as presented by Diniz (2015, 2018) and Frezatti (2018). These are added to include behaviors related to productivism, which are common in the postgraduate environment, as shown in Table 1. 
Table 1

Categorization of dishonest behaviors

\begin{tabular}{ll}
\hline Categories & Academically dishonest behaviors \\
\hline 1. Fraud/cheating & $\begin{array}{l}\text { Using notes in an exam; copying another student during a test; using some method to obtain a test before it is } \\
\text { applied; copying a peer without authorization during an exam; helping someone else cheat in a test; cheating } \\
\text { in some way in an assessment; actively and passively cheating; multiple paper submissions; deception and } \\
\text { adulteration (falsifying signatures, letters, and credentials); concealment (benefiting from a mistaken grade } \\
\text { or deceiving the teacher, pretending not to have noticed); lies and manipulation; using false information for } \\
\text { self-benefit, including emotional appeal; manipulation of rules set by the teacher, using them in your favor, or } \\
\text { refusing to apply those rules, as they are detrimental to you; dishonesty through computational access. }\end{array}$ \\
\hline 2. Helping other students & $\begin{array}{l}\text { Receiving unauthorized help in a task; collaborating in an individual task when the teacher asked for it to be } \\
\text { done alone; forging participation in a group; working in a group in a segmented way. }\end{array}$ \\
\hline 3. Plagiarism & $\begin{array}{l}\text { Copying material, transforming it into your own work; copying phrases from published material without } \\
\text { providing the appropriate reference. }\end{array}$ \\
\hline 4. Fabricating information & $\begin{array}{l}\text { Fabricating or falsifying a bibliography; transforming a paper written by someone else; altering or inventing } \\
\text { data from practical classroom reports, from an experiment, or manipulation of data to force a result. }\end{array}$ \\
\hline 5. Self-plagiarism/similarities & $\begin{array}{l}\text { Self-plagiarism: "A case in which a text is identified as having a high degree of similarity with other texts from } \\
\text { the same author" (Diniz, 2015, p. 239). Self-plagiarism is used as productivism, that is, the author benefits } \\
\text { again through recognition of something that was already communicated. Similarity in research is linked to } \\
\text { productivism. It is popularly known as "salami research." Similarity can be treated in two ways: similarities } \\
\text { in whole articles, where one article is actually divided into two; and similarity in sections of articles, where } \\
\text { material is retrieved from one article to be used in another. }\end{array}$ \\
\hline
\end{tabular}

Source: Elaborated by the authors based on Diniz (2015, 2018), Frezatti (2018), McCabe and Trevino (1993), Pavela (1997), and Sousa et al. (2016).

Engagement in academic dishonesty should be avoided in HEIs, primarily through clarifying what does or does not constitute it, as well as what the penalties are for students who engage in such practices. As one of the results of their research, O'Neill and Pfeiffer (2012) found the need for students to understand the seriousness of dishonest behavior. The aforementioned authors state that the existence of a rule of conduct can help in this exercise, although it may not prevent academic dishonesty.

Studies on misconduct in research question the pressure for productivism, which is indirectly encouraged by the current research environment (Andrade, 2011). Vilaça (2018) states that one of the most important factors for assessing the science relates to published articles, preferably in good journals. The author laments the weight of responsibility lying wholly with the researcher when it comes to good conduct and questions what HEIs are doing to create an environment of research integrity, since, at the same time they communicate what should be done, they also encourage more publications.

The categorization of academic dishonesty shows how the analysis of the dishonest behaviors and penalties will be conducted. As can be seen below, the correlated studies were developed considering the discussion about academic dishonesty, the penalties, and the motivations for the behaviors that are seen as dishonest.

\subsection{Previous Studies and Research Hypotheses}

The international and national studies have addressed academic dishonesty based on different focuses within the context of teaching in the areas of management, chemistry, marketing, pedagogy, health, engineering, law, business, and accounting. Thus, in this section, the studies are listed independently of the area analyzed.

In undergraduate studies, Blankenship and Whitley (2000) sought to examine the relationship between cheating and other forms of dishonest behavior. The study showed that students who reported involvement in academic dishonesty also showed personal insecurity and a tendency to assume risks.

Simon et al. (2004) conducted their research in 15 undergraduate courses in chemistry at the University of Nevada, in the United States. Their objective was to explain why the students chose to report or not report cases of academic dishonesty, indicating the student's commitment and the key factors that determinine academic integrity. The students who believed that their teachers cared about their learning were willing to report dishonest peers.

In Brazil, regarding the aspect of cheating, Pimenta (2010) analyzed how this dishonest behavior is perceived by students and teachers of courses in law, management, pedagogy, and engineering in public and private HEIs. According to the teachers, large classes provide conditions 
for cheating and $95 \%$ of the teachers observe this practice in the classroom.

Veludo-de-Oliveira et al. (2014) analyzed dishonest attitudes of students in the area of business, such as cheating and plagiarism, and perceived that more than $90 \%$ of the students believe that other students have engaged in dishonest practices in the classroom. The results suggest that students who get involved in situations of dishonesty at school may get involved in them again, thus compromising the corporate environment through fraud (Veludo-de-Oliveira et al., 2014).

In the search for explanations for academic dishonesty, some authors have investigated the relationship between personality traits and academically dishonest behaviors. Avelino and Lima (2017) verified whether narcissistic personality traits affect the probability of accounting students presenting behaviors that could be considered dishonest in academia. The evidence shows that, on average, students tend to present narcissistic characteristics, such as obstinacy when pursuing objectives and success, a preference for individual production, and difficulty expressing feelings that involve conflicts, among others. Moreover, $64.7 \%$ of the students said that they had been involved in academic dishonesty. However, the authors concluded that, in the sample studied, higher levels of narcissism do not imply a direct impact over academic dishonesty.

In the same line of reasoning, Nasu and Afonso (2020) analyzed the relationship between cynicism and expectations of cheating in the academic and professional lives of 92 students in lato sensu postgraduate courses in accounting. The authors found evidence that cynicism has a positive relationship with expectations of cheating in academic and professional life; that is, the higher the cynicism trait in the individual, the more they are expected to cheat in the future. Nasu and Afonso (2020) indicate that the habit of cheating can become a vicious circle and recommend that policies and codes of conduct are adopted to reduce cheating due to cynicism. The conclusions of Avelino and Lima (2017) and Nasu and Afonso (2020) are interesting within the teaching environment, as they add to the literature the idea that evaluating personality traits can help in addressing academic dishonesty.

Through another prism, in a sample of 451 undergraduate students of accounting, Santos et al. (2020) found that academic dishonesty may be a way for students to make up for perceived injustice in the educational environment. In other words, the authors concluded that, in the presence of injustice, dishonesty tends to be manifested and may be a way for students to mitigate distributive injustice (concerning the distribution of grades), procedural injustice (related to grade criteria), or interactional injustice (regarding the student-teacher relationship) in the academic environment.

Focusing more specifically on the public involved in stricto sensu postgraduate courses, Andrade (2011) found evidence of the involvement of accounting researchers in inappropriate practices, although with a low frequency (rarely or occasionally). Among the 17 misconducts evaluated, the most recurrent ones were giving credit to authors who did not actually contribute to a paper and enlarging the references section with citations of unread sources cited in other articles.

Andrade (2011) explains that the researchers participating in the data collection (master's graduates, master's students, and doctoral students) and the experienced researchers interviewed believe that the need to publish is the most important factor influencing misconduct in research. The latter group also indicated that the need to publish is associated with the assessment system imposed on postgraduate programs by the Coordination for the Improvement of Higher Education Personnel (Capes).

Ferreira et al. (2013) investigated the perceptions of the students of stricto sensu postgraduate courses regarding the occurrence of plagiarism at USP. The results indicated that the students are aware of plagiarism and that engagement in this practice is deliberate, with the aim of obtaining a better academic result. The authors observed the individual difficulties in scientific writing, which lead to inefficiency in citing sources and references.

Drawing nearer to the proposal of the present research is the study by Braun and Stallworth (2009), who analyzed the perceptions of 458 students and 177 teachers of accounting in relation to academic dishonesty and the penalties applied to identify a "expectations gap," described by the authors as differences between students' and teachers' perceptions. The results did not present significant differences in the perceptions related to the clearly honest or dishonest behaviors, but there were divergences in the perception of "gray" cases (hard cases to classify as honest or dishonest). The teachers attributed harsher penalties than the students, thus indicating the existence of an expectations gap.

Based on the aforementioned studies, notably that of Braun and Stallworth (2009), on the concepts related to academic dishonesty, and on the possible expectations gap between students and teachers in postgraduate programs in accounting, the first research hypothesis and its components are presented as follows: 
$\mathrm{H}_{1}$ : students' and teachers' perceptions regarding academic dishonesty in stricto sensu postgraduate courses in accounting in Brazil are different.

$\mathrm{H}_{1 \mathrm{a}}$ : students are less strict in their assessment of academic dishonesty than teachers, in the students' view.

$\mathrm{H}_{1 \mathrm{~b}}$ : teachers are stricter than students in their assessment of academic dishonesty, in the teachers' view.

$\mathrm{H}_{1 \mathrm{c}}$ : students perceive teachers' assessments regarding academic dishonesty to be stricter than they really are.

$\mathrm{H}_{1 \mathrm{~d}}$ : teachers perceive students' assessments regarding academic dishonesty to less strict than they really are.

Regarding the undergraduate course in accounting, two similar studies to this one were found concerning the aim of evaluating the perception of teachers and students with respect to academic dishonesty: that of Oliveira and Chacarolli (2013) and that of Oliveira et al. (2014). As in previous papers, the studies indicate differences in perceptions in gray cases alone; that is, those that are hard to identify as honest or dishonest. The cases clearly defined as honest and dishonest did not present significant differences, which corroborates the results of Braun and Stallworth (2009).

Considering that certain cases are hard to classify as academically honest or dishonest, which are identified by Braun and Stallworth (2009) as gray cases, we have the second and final research hypothesis:
$\mathrm{H}_{2}$ : differences in perceptions of academic dishonesty are more likely to occur in gray cases, that is, in situations that are hard to classify as honest or dishonest.

In addition to perceptions regarding the categories of academic dishonesty, this study analyzes perceptions regarding the penalties applied for behaviors that are considered to be dishonest, both by students and by teachers, thus following the proposals of Braun and Stallworth (2009), Oliveira and Chacarolli (2013), and Oliveira et al. (2014), the latter of which also encouraged a discussion about the possible motivations for academic dishonesty, thus aligning with the present study.

Adding to previous studies, this research sought to triangulate between the perception of students and teachers and the perspective of HEIs, whose analysis considered the general statute of the university, the regulations of the postgraduate program in accounting, the student disciplinary code, the information obtained from the coordinations of some of the programs, and other information obtained from the web portals of the HEIs, as according to the procedures described below. Therefore, the main differentials of this study in relation to previous ones are its analysis of perceptions regarding academic dishonesty by categories and its investigation of programs concerning dishonest practices and penalties, within the context of stricto sensu postgraduate courses in accounting in Brazil.

\section{METHODOLOGICAL PROCEDURES}

\subsection{Population and Sample}

According to the latest data available from the Capes web portal at the time of carrying out this research (January to June of 2019), in 2017 in Brazil there were 35 stricto sensu postgraduate programs in accounting, divided into 50 courses (30 academic master's courses, five professional master's courses, and 15 doctorates). With this, the estimated population for this research was 860 students (it was considered that there were 20 active students in each master's group and 10 active students in each doctorate group). The population of teachers was 502 (Capes, 2019, May 10).

After applying the questionnaires, a sample of 86 students (10\% of the estimated population) and 48 teachers ( $9.6 \%$ of the population) was obtained. Therefore, the research is limited in relation to the sample size, which makes it impossible to generalize the results.

\subsection{Research Instruments}

To achieve the proposed aim of this study, two research instruments (questionnaires) were used, adapted from the studies of Braun and Stallworth (2009) and Oliveira and Chacarolli (2013), one of which was used on the students and the other was used on the teachers. The questionnaires contemplate situations that involve clearly honest and clearly dishonest behaviors and gray cases, that is, those that involve behaviors that are not clearly honest or dishonest, as well as describing the penalties to be applied by the students and teachers.

The original questionnaire of Braun and Stallworth (2009) is composed of four situations that contemplate two cases each (1A, 1B, 2A, 2B, 3A, 3B, 4A, and 4B). According to Braun and Stallworth (2009), the use of fictitious cases, but which represent real situations, facilitates identification with the situations perceived by 
the students and teachers, but also maintaining neutrality. The author used the feedback of 10 students on the realism of the instrument and accuracy of the classification of the cases into honest, dishonest, and the so-called gray cases.

The categorization described by Pavela (1997) was used to adapt the questionnaire, complemented by the dishonest behaviors indicated by Diniz $(2015,2018)$ and Frezatti (2018). At the time of allocating the cases to the categories, cases of fraud ( $1 \mathrm{~A}$ and $1 \mathrm{~B})$, helping other students to engage in academic dishonesty (2A and $2 \mathrm{~B})$, plagiarism $(3 \mathrm{~A}, 3 \mathrm{~B}$, and $4 \mathrm{~B})$, and self-plagiarism (4A) were identified in the original questionnaire, which were complemented by the creation of cases that reveal situations of fabricating information (5A and $5 \mathrm{~B})$ and self-plagiarism/similarities (6A and 6B), as according to Table 2.

\section{Table 2}

Categorization of the dishonest behaviors versus situations in the questionnaire

\begin{tabular}{|c|c|c|}
\hline Categories & Situations & Components of the situations (cases) \\
\hline 1. Fraud/cheating & 1 & $\begin{array}{c}\text { 1A (gray); } \\
\text { 1B (dishonest) }\end{array}$ \\
\hline 2. Helping other students & 2 & $\begin{array}{l}\text { 2A (dishonest); } \\
\text { 2B (gray) }\end{array}$ \\
\hline 3. Plagiarism & 3 and 4 & $\begin{array}{l}\text { 3A (dishonest); } \\
\text { 3B (honest); } \\
\text { 4B (dishonest) }\end{array}$ \\
\hline 4. Fabricating information & 5 & $\begin{array}{l}\text { 5A (dishonest); } \\
\text { 5B (honest) }\end{array}$ \\
\hline 5. Self-plagiarism/similarities & 4 and 6 & $\begin{array}{l}\text { 4A (gray); } \\
\text { 6A (gray); } \\
6 \mathrm{~B} \text { (honest) }\end{array}$ \\
\hline
\end{tabular}

Source: Elaborated by the authors based on Braun and Stallworth (2009), Diniz (2015, 2018), Frezatti (2018), Oliveira and Chacarolli (2013), and Pavela (1997).

The research instrument was also adapted in relation to the penalties, since for each behavior the students and teachers would apply a penalty. In the original instrument there were five penalties: 1 - no penalty; 2 - redoing the activity; 3 - reducing or zeroing the weight of the activity for the students involved; 4 - failing the entire group for that activity; 5 - referring offenders to the disciplinary committee of the teaching institution. In the adaptation, penalty 4 was removed, considering that it was not applicable in postgraduate programs. To evaluate academic dishonesty, a continuous scale was used, ranging from 0 (honest behavior) to 10 (dishonest behavior).

Both questionnaires (students and teachers) have the same number of situations and the same content. The only difference between the questionnaires is that the instrument applied requires the perception of each group (students and teachers) regarding academic dishonesty and the perception of how each group believes the other group evaluates the situations presented. This is also the case for the penalties imposed for the behaviors reflected in each situation, which are also required.

It should be noted that the research project was submitted to the human research ethics committee (REC) and the pre-test of the questionnaires was carried out with individuals from each one of the two groups investigated (six students and six teachers), in the period from $03 / 20$ to $05 / 05 / 2019$. The reliability of the instruments was tested using the Cronbach's alpha coefficient ( $\alpha$ ), whose result was $\alpha=0.95$ for the students and $\alpha=0.85$ for the teachers.

\subsection{Data Collection and Analysis Procedures}

The questionnaire, made available on the Google Docs platform, was sent by email to all of the teachers listed on the institutional websites of the programs and, for the students, it was sent by the coordinators of the programs. A timeframe was set for answering the questionnaires, corresponding to the period from $05 / 12$ to $07 / 15 / 2019$ for the students and the period from $06 / 02$ to $07 / 15 / 2019$ for the teachers. Additional appeals were needed to obtain the answers, sent via email to encourage the participants to answer the questionnaires.

With regards to the HEIs, the assessment of the stricto sensu postgraduate programs in accounting was based on verifying the existence or not of rules relating to academic dishonesty, considering: 1) the general statute of the university; 2) the regulations of the postgraduate program; 3 ) the student disciplinary code; and 4) additional information provided by the coordinator and information present on the web portals of the institutions. Regarding item 4 , information was requested from the coordinator by 
email about the rules concerning academically dishonest behaviors, as well as reports of any cases, if there was one.

To analyze the data relating to the students' and teachers' perceptions regarding academic dishonesty, the statistical techniques used were: a) descriptive statistics, to analyze the perceptions of each group; b) the Mann-
Whitney non-parametric $U$ test, to compare the means between the groups; and c) the Wilcoxon non-parametric test, to compare the participants' opinion in relation to the perception of the other group. Descriptive statistics were used to analyze the penalties for academic dishonesty and the regulations.

\section{ANALYSIS AND DISCUSSION OF THE RESULTS}

\subsection{Descriptive Analysis of Academic Dishonesty by Category}

This section will provide a descriptive analysis of the situations proposed by the following categorization: 1) fraud/cheating; 2) helping other students to engage in academic dishonesty; 3) plagiarism; 4) fabricating information, references, or results; and 5) self-plagiarism and similarities in studies.

Table 3 compares the perceptions of students and teachers, whose attributed scores (situations $2 \mathrm{~B}, 3 \mathrm{~B}, 5 \mathrm{~B}$, and 6B) impacted the high variability of the coefficients of variation. Despite some presenting 0 scores and scores close to 0 (honesty), there were students and teachers who attributed a score of 10 (dishonest).

Table 3

Academic dishonesty - students' perception versus teachers' perception

\begin{tabular}{|c|c|c|c|c|c|c|c|c|c|c|c|c|}
\hline \multirow[b]{2}{*}{ Situations } & \multicolumn{2}{|c|}{1 Fraud/cheating } & \multicolumn{2}{|c|}{$\begin{array}{l}\text { 2. Helping other } \\
\text { students }\end{array}$} & \multicolumn{3}{|c|}{ 3. Plagiarism } & \multicolumn{2}{|c|}{$\begin{array}{l}\text { 4. Fabricating } \\
\text { information }\end{array}$} & \multicolumn{3}{|c|}{ 5. Self-plagiarism/similarities } \\
\hline & $1 \mathrm{~A}$ & 1B & $2 A$ & 2B & $3 A$ & 3B & 4B & $5 \mathrm{~A}$ & 5B & $4 \mathrm{~A}$ & $6 \mathrm{~A}$ & 6B \\
\hline \multicolumn{13}{|l|}{ Students } \\
\hline Mean & 3.49 & 6.34 & 4.90 & 1.13 & 7.58 & 1.56 & 9.65 & 9.12 & 0.84 & 7.11 & 5.32 & 0.92 \\
\hline SD & 3.06 & 3.42 & 3.28 & 2.73 & 3.17 & 2.98 & 1.65 & 1.81 & 2.68 & 2.95 & 3.58 & 2.15 \\
\hline Median & 4.00 & 7.00 & 5.00 & 0.00 & 9.00 & 0.00 & 10.00 & 10.00 & 0.00 & 8.00 & 5.00 & 0.00 \\
\hline $\mathrm{CV} \%$ & 87.64 & 53.85 & 66.85 & 242.44 & 41.81 & 191.55 & 17.10 & 19.82 & 320.43 & 41.53 & 67.28 & 234.50 \\
\hline \multicolumn{13}{|l|}{ Teachers } \\
\hline Mean & 4.54 & 7.60 & 6.44 & 1.57 & 8.43 & 1.17 & 9.04 & 9.17 & 0.63 & 7.90 & 7.51 & 1.57 \\
\hline SD & 3.45 & 2.86 & 2.73 & 2.83 & 2.47 & 2.64 & 2.85 & 2.29 & 1.79 & 2.65 & 2.45 & 3.13 \\
\hline Median & 5.00 & 8.00 & 7.00 & 0.00 & 10.00 & 0.00 & 10.00 & 10.00 & 0.00 & 9.00 & 8.00 & 0.00 \\
\hline CV \% & 76.16 & 37.69 & 42.34 & 179.99 & 29.34 & 225.97 & 31.53 & 24.99 & 287.02 & 33.49 & 32.66 & 199.76 \\
\hline
\end{tabular}

$C V=$ coefficient of variation; $S D=$ standard deviation; maximum $=10.00$ in all situations; minimum $=0.00$.

Source: Elaborated by the authors.

In the comparison of the students' and teachers' perceptions, in almost all of the situations there was similarity between the means, except in situations $1 \mathrm{~B}$ (dishonest case), 2A (dishonest case), and 6A (gray case), which presented greater differences in the means, underlining a divergence in perceptions in categories 1 , 2 , and 5 .

In situation $1 \mathrm{~B}$, although it is a dishonest attitude (passing notes), it was not evaluated so clearly by the students, as the mean was 6.34 , indicating difficulty in classifying the situation as honest or dishonest. In situation $1 \mathrm{~A}$, the teachers are not convinced that discussing the content of the test with other students, even when knowing that the test to be applied will be the same, is a dishonest behavior, as the mean was 4.54 . However, in situation $1 \mathrm{~B}$ (passing notes to another student) the teachers perceive the behavior as dishonest (mean of 7.60).

In situation $2 \mathrm{~A}$, the mean of 4.9 reveals the students' difficulty in classifying the situation as honest or dishonest, despite the behavior (including the name of peers who did not participate in a paper) not leaving any doubt. If we compare the result for situation $2 \mathrm{~A}$ with the one obtained for situation $2 \mathrm{~B}$, which concerns teamwork being elaborated by each member in isolation, it can 
be observed that, for the students, segmented work is a common practice in postgraduate studies, as the mean of 1.13 indicates honest behavior, although it is a gray case. The perception of most of the teachers (mean of 1.57) and of the students (mean of 1.13) is similar (honest behavior).

In situation $6 \mathrm{~A}$, most of the students could not classify the behavior as dishonest or honest (mean of 5.32). This may denote that the students do not consider using parts of previously published papers of their own authorship as opportunism (self-plagiarism/similarities), perhaps even due to the fact that the case indicates that the content used relates to the introduction and the literature review. On the other hand, most of the teachers had no doubts in classifying the situation as dishonest (mean of 7.51).

In summary, from the simple comparison between the means of each case analyzed, there are indications that the students' and teachers' perceptions are aligned regarding the categories of fabricating information and plagiarism and they are partially aligned regarding the categories of fraud/cheating, helping other students, and self-plagiarism/similarities. There now follows an analysis of the statistical significance of the students' and teachers' perceptions.

\subsection{Students' and Teachers' Perceptions Regarding Academic Dishonesty}

Table 4 presents the results of the statistical test of hypothesis $\mathrm{H}_{1}$. The scores attributed by the students and teachers to the situations expressed in the questionnaire were submitted to the Mann-Whitney $U$ test, a nonparametric statistical test, whose adopted level of significance was 0.05 , to compare the perceptions of the two groups regarding academic dishonesty in stricto sensu postgraduate courses in accouting.

Table 4

Perceptions of dishonest behavior: students' perception versus teachers' perception

\begin{tabular}{|c|c|c|c|c|}
\hline \multirow[b]{2}{*}{ Category } & \multirow[b]{2}{*}{ Situation } & \multicolumn{2}{|c|}{ Perception } & \multirow[b]{2}{*}{ p-value } \\
\hline & & $\begin{array}{c}\text { Students } \\
\text { (mean) }\end{array}$ & $\begin{array}{c}\text { Teachers } \\
\text { (mean) }\end{array}$ & \\
\hline \multirow{2}{*}{ 1. Fraud/cheating } & $1 \mathrm{~A}$ & 3.49 & 4.54 & 0.063 \\
\hline & $1 \mathrm{~B}$ & 6.34 & 7.60 & $0.023^{*}$ \\
\hline \multirow{2}{*}{ 2. Helping other students } & $2 \mathrm{~A}$ & 4.90 & 6.44 & $0.009 *$ \\
\hline & $2 \mathrm{~B}$ & 1.13 & 1.57 & 0.063 \\
\hline \multirow{3}{*}{ 3. Plagiarism } & $3 \mathrm{~A}$ & 7.58 & 8.43 & 0.071 \\
\hline & $3 B$ & 1.56 & 1.17 & 0.886 \\
\hline & $4 \mathrm{~B}$ & 9.65 & 9.04 & 0.166 \\
\hline \multirow{2}{*}{ 4. Fabricating information } & $5 \mathrm{~A}$ & 9.12 & 9.17 & 0.113 \\
\hline & $5 B$ & 0.84 & 0.63 & 0.060 \\
\hline \multirow{3}{*}{ 5. Self-plagiarism/similarities } & $4 \mathrm{~A}$ & 7.11 & 7.90 & 0.112 \\
\hline & $6 \mathrm{~A}$ & 5.32 & 7.51 & $0.001^{*}$ \\
\hline & $6 \mathrm{~B}$ & 0.92 & 1.57 & 0.119 \\
\hline
\end{tabular}

* = significant at a nominal significance level of 0.05.

Source: Elaborated by the authors.

Considering the p-value lower than 0.05 found in only three of the 12 situations, hypothesis $\mathrm{H}_{1}$ is rejected, which states that the students' and teachers' perceptions regarding academic dishonesty in stricto sensu postgraduate courses in accounting in Brazil are different. Complete alignment can also be observed between the students' and teachers' perceptions in two categories (plagiarism and fabricating information), while the other three categories present differences in at least one of the situations presented.

The divergences are found in category 1 (situation of fraud/cheating), in category 2 (the highly common situation of teamwork in postgraduate studies, where a paper is authored by one student, but all are considered as participants by the author), and in category 5 (which portrays using parts of an article by a doctoral student, as according to the hypothetical situation). It is worth noting that, although they do not occur in all of the situations, there are differences in the students' and teachers' perceptions regarding academic dishonesty that need to be evaluated by the postgraduate programs.

Table 5 shows the statistical results relating to the test of hypothesis $\mathrm{H}_{1}$, which states that students are less strict when assessing academic dishonesty than teachers, in the 
students' view. The test applied was the paired Wilcoxon test, which was used to compare the students' perception with the perception the students have in relation to the teachers' perception.

Table 5

Academic dishonesty: self-assessment of one group in relation to the other

\begin{tabular}{|c|c|c|c|c|c|c|c|}
\hline \multirow[b]{2}{*}{ Categories } & \multirow[b]{2}{*}{ Situation } & \multicolumn{2}{|c|}{ Perception } & \multirow[b]{2}{*}{ p-value } & \multicolumn{2}{|c|}{ Perception } & \multirow[b]{2}{*}{ p-value } \\
\hline & & $\begin{array}{c}\text { Students } \\
\text { (mean) }\end{array}$ & $\begin{array}{c}\text { Students- } \\
\text { teachers } \\
\text { (mean) }\end{array}$ & & $\begin{array}{c}\text { Teachers } \\
\text { (mean) }\end{array}$ & $\begin{array}{c}\text { Teachers- } \\
\text { students } \\
\text { (mean) }\end{array}$ & \\
\hline \multirow{2}{*}{ 1. Fraud/cheating } & $1 \mathrm{~A}$ & 3.49 & 4.90 & $0.000^{*}$ & 4.54 & 2.29 & $0.000^{*}$ \\
\hline & 1B & 6.34 & 7.06 & $0.002^{*}$ & 7.60 & 4.18 & $0.000^{*}$ \\
\hline \multirow{2}{*}{$\begin{array}{l}\text { 2. Helping other } \\
\text { students }\end{array}$} & $2 \mathrm{~A}$ & 4.96 & 5.10 & 0.589 & 6.47 & 3.34 & $0.000^{*}$ \\
\hline & $2 \mathrm{~B}$ & 1.29 & 1.25 & 0.246 & 1.60 & 1.52 & 0.615 \\
\hline \multirow{3}{*}{ 3. Plagiarism } & $3 \mathrm{~A}$ & 7.22 & 7.48 & 0.813 & 8.43 & 5.38 & $0.000^{*}$ \\
\hline & $3 \mathrm{~B}$ & 1.99 & 1.65 & 0.131 & 1.17 & 1.17 & 0.671 \\
\hline & $4 \mathrm{~B}$ & 9.51 & 9.56 & 0.059 & 9.04 & 6.86 & $0.000^{*}$ \\
\hline \multirow{2}{*}{$\begin{array}{l}\text { 4. Fabricating } \\
\text { information }\end{array}$} & $5 \mathrm{~A}$ & 9.19 & 8.95 & 0.300 & 9.17 & 7.54 & $0.000^{*}$ \\
\hline & $5 B$ & 1.35 & 1.13 & 0.141 & 0.63 & 0.67 & 0.414 \\
\hline \multirow{3}{*}{$\begin{array}{l}\text { 5. Self-plagiarism/ } \\
\text { similarities }\end{array}$} & $4 \mathrm{~A}$ & 6.53 & 7.58 & $0.021^{*}$ & 7.90 & 4.84 & $0.000^{*}$ \\
\hline & $6 \mathrm{~A}$ & 5.32 & 5.81 & $0.011^{*}$ & 7.51 & 4.83 & $0.000 *$ \\
\hline & $6 B$ & 0.92 & 0.93 & 1.000 & 1.57 & 1.17 & 0.108 \\
\hline
\end{tabular}

* = significant at a nominal significance level of 0.05 .

Source: Elaborated by the authors.

The results show significant differences in perceptions (students' assessment versus that group's view in relation to the assessment teachers would make) in two categories (fraud/cheating and self-plagiarism/similarities), while three categories (helping other students, plagiarism, and fabricating information) presented statistically similar means. Considering the differences in perceptions in only two categories (four situations), hypothesis $\mathrm{H}_{1 \mathrm{a}}$ is partially rejected.

These results are different from those found in the research of Braun and Stallworth (2009), whose differences occurred for all of the cases. The study of Oliveira and Chacarolli (2013) accepted the hypothesis for six of the eight cases. These divergences in the results may be related to the context of stricto sensu postgraduate studies. Moreover, the fact that there are students who already teach is likely to influence the divergences between the studies.

Table 5 also shows the test of hypothesis $\mathrm{H}_{1 \mathrm{~b}}$, which states that teachers are stricter when evaluating academic dishonesty than students, in the teachers' view. Analyzing categories 2, 3, 4, and 5, in at least one of the cases there is a statistically significant difference. Thus, with the exception of the fraud/cheating category, in which the perceptions are different in the two situations, all of the other categories have similar perceptions in at least one situation, implying partial rejection of hypothesis $\mathrm{H}_{1 b}$.

These results are similar to those of the study by Braun and Stallworth (2009), which obtained a significant difference for all of the cases. The Brazilian study (Oliveira \& Chacarolli, 2013) presented a difference in only two cases. The difference found between this study and the previous one by Oliveira and Chacarolli (2013) may be due to the target public being different or even a result of the coverage of the present study, which involved teachers from the whole country.

In Table 6, the Mann-Whitney $U$ statistical test was used to verify the accuracy of the each group's perception in relation to the other, as described in hypothesis $\mathrm{H}_{1 \mathrm{c}}$ (students perceive teachers' assessments in relation to academic dishonesty as being stricter than they really are). The significant differences are found in categories 2 and 5 (helping other students and self-plagarism/similarities). The other categories are similar, in that the students' perception about the teachers is close to the teachers' view. Hypothesis $\mathrm{H}_{1 \mathrm{c}}$ was rejected, since in the students' view the teachers are no stricter than they really are, thus only confirming the difference in perception for situations $2 \mathrm{~A}$ and $6 \mathrm{~A}$. 
Table 6

Accuracy of one group's assessment in relation to the other group's perception

\begin{tabular}{|c|c|c|c|c|c|c|c|}
\hline \multirow[b]{2}{*}{ Categories } & \multirow[b]{2}{*}{ Situation } & \multicolumn{2}{|c|}{ Perception } & \multirow[b]{2}{*}{ p-value } & \multicolumn{2}{|c|}{ Perception } & \multirow[b]{2}{*}{ p-value } \\
\hline & & $\begin{array}{c}\text { Students-teachers } \\
\text { (mean) }\end{array}$ & $\begin{array}{c}\text { Teachers } \\
\text { (mean) }\end{array}$ & & $\begin{array}{l}\text { Teachers-students } \\
\text { (mean) }\end{array}$ & $\begin{array}{c}\text { Students } \\
\text { (mean) }\end{array}$ & \\
\hline \multirow{2}{*}{ 1. Fraud/cheating } & $1 \mathrm{~A}$ & 4.90 & 4.54 & 0.452 & 2.29 & 3.49 & $0.033^{*}$ \\
\hline & 1B & 7.06 & 7.60 & 0.626 & 4.18 & 6.34 & $0.000^{*}$ \\
\hline \multirow{2}{*}{$\begin{array}{l}\text { 2. Helping other } \\
\text { students }\end{array}$} & $2 \mathrm{~A}$ & 5.10 & 6.44 & $0.009 *$ & 3.34 & 4.90 & $0.010^{*}$ \\
\hline & $2 B$ & 1.25 & 1.57 & 0.060 & 1.52 & 1.13 & 0.154 \\
\hline \multirow{3}{*}{ 3. Plagiarism } & $3 \mathrm{~A}$ & 7.48 & 8.43 & 0.057 & 5.38 & 7.58 & $0.000^{*}$ \\
\hline & $3 \mathrm{~B}$ & 1.65 & 1.17 & 0.907 & 1.17 & 1.56 & 0.703 \\
\hline & $4 \mathrm{~B}$ & 9.56 & 9.04 & 0.506 & 6.86 & 9.65 & $0.000^{*}$ \\
\hline \multirow{2}{*}{$\begin{array}{l}\text { 4. Fabricating } \\
\text { information }\end{array}$} & $5 \mathrm{~A}$ & 8.95 & 9.17 & 0.084 & 7.54 & 9.12 & $0.000^{*}$ \\
\hline & $5 B$ & 1.13 & 0.63 & 0.238 & 0.67 & 0.84 & 0.100 \\
\hline \multirow{3}{*}{$\begin{array}{l}\text { 5. Self-plagiarism/ } \\
\text { similarities }\end{array}$} & $4 \mathrm{~A}$ & 7.58 & 7.90 & 0.552 & 4.84 & 7.11 & $0.000^{*}$ \\
\hline & $6 \mathrm{~A}$ & 5.81 & 7.51 & $0.015^{*}$ & 4.83 & 5.32 & 0.426 \\
\hline & $6 B$ & 0.93 & 1.57 & 0.122 & 1.17 & 0.92 & 0.321 \\
\hline
\end{tabular}

* = significant at a nominal significance level of 0.05 .

Source: Elaborated by the authors.

The similarities presented in categories 1, 3, and 4 are relevant, as they indicate that the stricto sensu postgraduate students of accounting have a closer view of the teachers' perception in these categories and they do not consider the teachers' assessment to be any stricter than it really is. As they are mostly courses that train teachers and researchers, this alignment is a positive factor, since it can help HEIs in implementing policies for combatting academic dishonesty. However, the two categories that presented divergences in the situations (categories 2 and 5) need to be discussed within the academic environment.

The result for this hypothesis is close to the result of the research of Oliveira and Chacarolli (2013), whose statistical difference occurred in two cases, and close to that of the research of Braun and Stallworth (2009), with a difference in only one case. This result indicates that, in Brazil, despite the proximity between students' and teachers' perceptions, in the study of Braun and Stallworth (2009), the students were more accurate in the perception they have of teachers.

Hypothesis $\mathrm{H}_{1 \mathrm{~d}}$ (Table 6) compared whether the teachers perceive the students' assessments in relation to academic dishonesty as being less strict than they really are. There were significant differences in two situations in categories 1 and 3 and, in another three categories, at least one situation presented a significant difference. Considering the results, hypothesis $\mathrm{H}_{1 \mathrm{~d}}$ is partially rejected, as some situations presented similarities in the perceptions. In most of the cases, the teachers' expectations in relation to the students is that the latter are more tolerant than they really are.

The analysis of hypothesis $\mathrm{H}_{1 \mathrm{~d}}$ is consistent with the research of Braun and Stallworth (2009), in which the significant differences occurred in six of the eight cases. The study of Oliveira and Chacarolli (2013) presented differences in four of the eight cases.

Hypothesis $\mathrm{H}_{2}$ tests whether the differences in the perceptions of academic dishonesty are more likely to occur in situations with gray cases. Analyzing the gray cases, these occurred in three categories: fraud/cheating, helping other students, and self-plagiarism/similarities, and there was only a significant difference in the last category, corresponding to situation $6 \mathrm{~A}$, as shown in Table 7 . The other situations with gray cases $(1 \mathrm{~A}, 2 \mathrm{~B}$, and $4 \mathrm{~A})$ did not present a significant difference. In light of the results, hypothesis $\mathrm{H}_{2}$ is not confirmed, since out of the three differences found, only one occurred in gray cases. 
Table 7

Differences in perceptions regarding academic dishonesty

\begin{tabular}{|c|c|c|c|c|c|}
\hline \multirow{2}{*}{ Category } & \multirow{2}{*}{ Situation } & \multirow{2}{*}{ Case } & \multicolumn{2}{|c|}{ Perception } & \multirow{2}{*}{ p-value } \\
\hline & & & Students (mean) & Teachers (mean) & \\
\hline \multirow{2}{*}{ 1. Fraud/cheating } & $1 \mathrm{~A}$ & Gray & 3.49 & 4.54 & 0.063 \\
\hline & $1 \mathrm{~B}$ & Dishonest & 6.34 & 7.60 & $0.023 *$ \\
\hline \multirow{2}{*}{$\begin{array}{l}\text { 2. Helping other } \\
\text { students }\end{array}$} & $2 \mathrm{~A}$ & Dishonest & 4.90 & 6.44 & $0.009^{*}$ \\
\hline & $2 \mathrm{~B}$ & Gray & 1.13 & 1.57 & 0.063 \\
\hline \multirow{3}{*}{ 3. Plagiarism } & $3 \mathrm{~A}$ & Dishonest & 7.58 & 8.43 & 0.071 \\
\hline & $3 \mathrm{~B}$ & Honest & 1.56 & 1.17 & 0.886 \\
\hline & $4 \mathrm{~B}$ & Dishonest & 9.65 & 9.04 & 0.166 \\
\hline \multirow{2}{*}{$\begin{array}{l}\text { 4. Fabricating } \\
\text { information }\end{array}$} & $5 \mathrm{~A}$ & Dishonest & 9.12 & 9.17 & 0.113 \\
\hline & $5 B$ & Honest & 0.84 & 0.63 & 0.060 \\
\hline \multirow{3}{*}{$\begin{array}{l}\text { 5. Self-plagiarism/ } \\
\text { similarities }\end{array}$} & $4 \mathrm{~A}$ & Gray & 7.11 & 7.90 & 0.112 \\
\hline & $6 \mathrm{~A}$ & Gray & 5.32 & 7.51 & $0.001 *$ \\
\hline & $6 B$ & Honest & 0.92 & 1.57 & 0.119 \\
\hline
\end{tabular}

* = significant at the nominal significance level of 0.05.

Source: Elaborated by the authors.

The significant differences occurred in two cases of dishonesty (1B and $2 \mathrm{~A}$ ) and in only one gray case (6A). This implies divergences in perceptions between students and teachers regarding clearly dishonest behaviors, while it was expected that the divergences could occur when the situations reflected harder behaviors to classify as honest/dishonest.
This result diverges from the research of Braun and Stallworth (2009), which presented a difference in five cases, and that of Oliveira and Chacarolli (2013), in which there was a difference in two cases. This may be due to the absence of more specific guidance and/or rules on the part of the programs or the HEIs with regards to academic dishonesty.

Table 8 presents a summary of the hypotheses and of the results found.

Table 8

Summary of the results for the hypotheses

\begin{tabular}{lcc}
\hline Hypothesis & Comparisons & Results \\
\hline $\begin{array}{l}\mathrm{H}_{1} \text { : students' and teachers' perceptions regarding academic dishonesty in } \\
\text { stricto sensu postgraduate courses in accounting in Brazil are different. }\end{array}$ & Teachers versus students & Rejected \\
\hline $\begin{array}{l}\mathrm{H}_{1 \mathrm{a}} \text { : students are less strict in their assessment of academic dishonesty than } \\
\text { teachers, in the students' view. }\end{array}$ & $\begin{array}{c}\text { Students versus students- } \\
\text { teachers }\end{array}$ & Partially rejected \\
\hline $\begin{array}{l}\mathrm{H}_{1 \mathrm{~b}} \text { : teachers are stricter than students in their assessment of academic } \\
\text { dishonesty, in the teachers' view. }\end{array}$ & $\begin{array}{c}\text { Teachers versus teachers- } \\
\text { students }\end{array}$ & Partially rejected \\
\hline $\begin{array}{l}\mathrm{H}_{1 \mathrm{c}} \text { : students perceive teachers' assessments in relation to academic } \\
\text { dishonesty as being stricter than they really are. }\end{array}$ & $\begin{array}{c}\text { Students-teachers versus } \\
\text { teachers }\end{array}$ & Rejected \\
\hline $\begin{array}{l}\mathrm{H}_{1 \mathrm{~d}} \text { : teachers perceive students' assessments in relation to academic } \\
\text { dishonesty as being less strict that they really are. }\end{array}$ & $\begin{array}{c}\text { Teachers-students versus } \\
\text { students }\end{array}$ & Partially rejected \\
\hline $\begin{array}{l}\mathrm{H}_{2}: \text { differences in perceptions of academic dishonesty are more likely to } \\
\text { occur in gray cases, that is, in situations that are hard to classify as honest or } \\
\text { dishonest. }\end{array}$ & $\begin{array}{c}\text { Students versus teachers } \\
\text { Rejected }\end{array}$ \\
\hline
\end{tabular}

Source: Elaborated by the authors.

In general, it can be stated that students' and teachers' perceptions regarding academic dishonesty in the context of stricto sensu postgraduate courses in accounting in Brazil do not differ, even in gray cases, notably in situations of plagiarism and fabricating information, results, and references, which are cases that may occur more often in the setting under focus. However, it has to be considered that in situations of fraud/cheating, helping others to engage in dishonest practices, and self-plagiarism/ similarities in studies, students' and teachers' perceptions are different, which should be further explored, including with regards to the applicable penalties. 


\subsection{Students' and Teachers' Perceptions Regarding the Penalties for Engaging in Academic Dishonesty}

Table 9 presents the students' versus the teachers' perception regarding the application of penalties in each one of the cases.

In the fraud/cheating category, in situation $1 \mathrm{~A}, 70.38 \%$ of the teachers and $82.52 \%$ of the students would not place a penalty on those involved, although $25 \%$ of the teachers would reduce their grade or ask them to redo the activity. This evaluation denotes a certain degree of acceptance of cheating, even by the teachers, as most would not apply a penalty.
In the category of helping other students to engage in academic dishonesty, most of the students (81.40\%) would not penalize the student involved for elaborating the paper and putting the name of their peers on it; however, only $47.92 \%$ of the teachers would not apply a penalty, showing a divergence in perception (situation 2A). In situation $2 \mathrm{~B}$, more than $90 \%$ of the students and teachers would not apply a penalty for carrying out teamwork in a segmented way. This is significant, since in postgraduate studies teamwork is common and most teachers did not consider team segmentation to be a dishonest behavior. To a certain degree, they even incentivize it, given that $95.83 \%$ would not apply any penalty.

Table 9

Students' perception versus teachers' perception - penalties in cases of dishonesty

\begin{tabular}{|c|c|c|c|c|c|c|c|c|}
\hline \multirow[b]{2}{*}{ Category } & \multirow[b]{2}{*}{ Situation } & \multirow[b]{2}{*}{ Case } & \multirow[b]{2}{*}{ Student } & \multicolumn{5}{|c|}{ Penalties (\%) } \\
\hline & & & & NP & RA & RZWA & DC & Total \\
\hline \multicolumn{9}{|l|}{ Students } \\
\hline \multirow{4}{*}{ 1. Fraud/cheating } & $1 \mathrm{~A}$ & Gray & Catarina & 82.56 & 8.14 & 5.81 & 3.49 & 100.00 \\
\hline & & & Jonas & 74.42 & 19.77 & 2.33 & 3.49 & 100.00 \\
\hline & $1 \mathrm{~B}$ & Dishonest & Antônia & 33.72 & 23.26 & 29.07 & 13.95 & 100.00 \\
\hline & & & Anderson & 32.56 & 33.72 & 27.91 & 5.81 & 100.00 \\
\hline \multirow{2}{*}{$\begin{array}{l}\text { 2. Helping other } \\
\text { students }\end{array}$} & $2 \mathrm{~A}$ & Dishonest & Rafael & 81.40 & 4.65 & 11.63 & 2.33 & 100.00 \\
\hline & $2 \mathrm{~B}$ & Gray & Roberta & 93.02 & 3.49 & 2.33 & 1.16 & 100.00 \\
\hline \multirow{3}{*}{ 3. Plagiarism } & $3 \mathrm{~A}$ & Dishonest & Henrique & 12.79 & 43.02 & 29.07 & 15.12 & 100.00 \\
\hline & $3 \mathrm{~B}$ & Honest & Paula & 82.56 & 15.12 & 1.16 & 1.16 & 100.00 \\
\hline & 4B & Dishonest & Angélica & 1.16 & 12.79 & 23.26 & 62.79 & 100.00 \\
\hline \multirow{2}{*}{$\begin{array}{l}\text { 4. Fabricating } \\
\text { information }\end{array}$} & $5 \mathrm{~A}$ & Dishonest & João Pedro & 1.16 & 41.86 & 30.23 & 26.74 & 100.00 \\
\hline & $5 B$ & Honest & Cinthia & 95.35 & 1.16 & 1.16 & 2.33 & 100.00 \\
\hline \multirow{3}{*}{$\begin{array}{l}\text { 5. Self- } \\
\text { plagiarism/ } \\
\text { similarities }\end{array}$} & $4 \mathrm{~A}$ & Gray & André & 18.60 & 47.67 & 25.58 & 8.14 & 100.00 \\
\hline & $6 \mathrm{~A}$ & Gray & Márcia & 44.19 & 23.26 & 20.93 & 11.63 & 100.00 \\
\hline & $6 B$ & Honest & Carlos & 95.35 & 3.49 & 0.00 & 1.16 & 100.00 \\
\hline \multicolumn{9}{|l|}{ Teachers } \\
\hline \multirow{4}{*}{ 1. Fraud/cheating } & $1 \mathrm{~A}$ & Gray & Catarina & 70.83 & 12.50 & 12.50 & 4.17 & 100.00 \\
\hline & & & Jonas & 68.75 & 16.67 & 12.50 & 2.08 & 100.00 \\
\hline & 1B & Dishonest & Antônia & 31.25 & 14.58 & 37.50 & 16.67 & 100.00 \\
\hline & & & Anderson & 29.17 & 25.00 & 35.42 & 10.42 & 100.00 \\
\hline \multirow{2}{*}{$\begin{array}{l}\text { 2. Helping other } \\
\text { students }\end{array}$} & $2 \mathrm{~A}$ & Dishonest & Rafael & 47.92 & 18.75 & 27.08 & 6.25 & 100.00 \\
\hline & $2 B$ & Gray & Roberta & 95.83 & 2.08 & 2.08 & 0.00 & 100.00 \\
\hline \multirow{3}{*}{ 3. Plagiarism } & $3 \mathrm{~A}$ & Dishonest & Henrique & 6.25 & 41.67 & 27.08 & 25.00 & 100.00 \\
\hline & $3 B$ & Honest & Paula & 91.67 & 4.17 & 4.17 & 0.00 & 100.00 \\
\hline & $4 \mathrm{~B}$ & Dishonest & Angélica & 2.08 & 12.50 & 16.67 & 68.75 & 100.00 \\
\hline \multirow{2}{*}{$\begin{array}{l}\text { 4. Fabricating } \\
\text { information }\end{array}$} & $5 \mathrm{~A}$ & Dishonest & João Pedro & 2.08 & 25.00 & 20.83 & 52.08 & 100.00 \\
\hline & $5 B$ & Honest & Cinthia & 97.92 & 2.08 & 0.00 & 0.00 & 100.00 \\
\hline \multirow{3}{*}{$\begin{array}{l}\text { 5. Self- } \\
\text { plagiarism/ } \\
\text { similarities }\end{array}$} & $4 \mathrm{~A}$ & Gray & André & 8.33 & 41.67 & 31.25 & 18.75 & 100.00 \\
\hline & $6 \mathrm{~A}$ & Gray & Márcia & 12.50 & 41.67 & 22.92 & 22.92 & 100.00 \\
\hline & $6 B$ & Honest & Carlos & 87.50 & 10.42 & 0.00 & 2.08 & 100.00 \\
\hline
\end{tabular}

Note: Values in bold correspond to the greatest divergences in the application of penalties by students and teachers. $D C=$ disciplinary committee; $N P=$ no penalty; $R A=$ redo the activity; $R Z W A=$ reduce or zero the weight of the activity.

Source: Elaborated by the authors 
In the plagiarism category, situation $3 \mathrm{~A}$ presents differences in the students' and teachers' perceptions, as $25 \%$ of the teachers would penalize the behavior by referring the offender to the disciplinary committee and only $15.12 \%$ of the students would assume this position. On the other hand, instead of applying the harshest penalty, most of the students and teachers would ask the offender to redo the activity, which, in an environment in which researchers (experienced or otherwise) predominate, would be an acceptable attitude that would offer an opportunity for learning and the advancement of knowledge.

The students' and teachers' positions in the fabricating information category are also different, as $41.86 \%$ of the students would ask the offender to redo the activity, while the teachers would apply a harsher penalty (referring the offender to the disciplinary committee) (52.08\%), according to situation $5 \mathrm{~A}$.

In the category of self-plagiarism and similarities in studies, it is perceived that the teachers are stricter in applying penalties in the three situations presented compared with the students. Situation 6A presents the greatest divergence, with the non-application of a penalty by $44.19 \%$ of the students, while only $12.5 \%$ of the teachers would not apply a penalty. According to Diniz (2015), similarity in studies occurs when one study generates more than one article and the difficulty lies in distinguishing between when there is merely an oversight in the text and when the similarity is motivated by academic opportunism.

Comparing these results with the research of Braun and Stallworth (2009), which found a difference in all of the penalties, and with the study by Oliveira and Chacarolli (2013), which obtained a difference in nine of the 10 categories presented, it is perceived that, in postgraduate studies, although there is a difference in perceptions, these appear to be less frequent than in undergraduate studies. This result was divergent from the previous correlated studies, probably due to the difference in the profile of the undergraduate students and in the profile of the postgraduate students, as some of these students already teach or are about to do so, which may cause similar perceptions to those of teachers. Another explanation could also be linked to the situations created in the questionnaire, which focus more on the context of postgraduate studies.

Based on the divergences in perceptions, it is verified that there is an expectations gap between teachers and students. The existence of clear rules regarding cases of academic dishonesty in the postgraduate programs probably helps in aligning students' and teachers' perceptions concerning the penalties to be applied, thus avoiding a gap in the perceptions of one group in relation to the other.

\subsection{Analysis of the Postgraduate Programs in Relation to Academic Dishonesty}

The evaluation of stricto sensu postgraduate programs in accounting was based on verifying the existence or not of rules relating to academic dishonesty. The results can be observed in Table 10 .

\section{Table 10}

Analysis of academic dishonesty in the postgraduate programs

\begin{tabular}{|c|c|c|c|c|c|c|}
\hline \multirow{3}{*}{ Teaching institutions } & \multicolumn{6}{|c|}{ Type of document with information about academic dishonesty } \\
\hline & \multicolumn{2}{|c|}{ General statute } & \multicolumn{2}{|c|}{ PGP regulations } & \multicolumn{2}{|c|}{ Disciplinary code } \\
\hline & Yes & No & Yes & No & Yes & No \\
\hline State University of West Paraná (UNIOESTE) & & $x$ & & $x$ & & $x$ \\
\hline Federal University of Rio Grande do Sul (UFRGS) & & $x$ & $\mathrm{x}$ & & $x$ & \\
\hline Mackenzie Presbiterian University (UPM) & & & & $*$ & $x$ & \\
\hline $\begin{array}{l}\text { Foundation Institute for Accounting, Actuarial, and Financial } \\
\text { Research (FIPECAFI) }\end{array}$ & & & & $*$ & & \\
\hline Pontifical Catholic University (PUC)** & & & $\mathrm{x}$ & & & \\
\hline University of Vale do Rio dos Sinos (UNISINOS) & & & $x$ & & & \\
\hline State University of Rio de Janeiro (UERJ) & & & $\mathrm{x}$ & & & \\
\hline Federal University of Ceará (UFC) & $\mathrm{x}$ & & & * & & \\
\hline Community University of the Chapecó Region (UNOCHAPECÓ) & $\mathrm{x}$ & & & $*$ & & \\
\hline University of Brasília (UNB) & $x$ & & & $*$ & & \\
\hline Regional University of Blumenau (FURB) & $x$ & & & $*$ & & \\
\hline Álvares Penteado Foundation School of Commerce (FECAP) & $\mathrm{x}$ & & & $x$ & & \\
\hline
\end{tabular}


Table 10

Cont.

\begin{tabular}{|c|c|c|c|c|c|c|}
\hline \multirow{3}{*}{ Teaching institutions } & \multicolumn{6}{|c|}{ Type of document with information about academic dishonesty } \\
\hline & \multicolumn{2}{|c|}{ General statute } & \multicolumn{2}{|c|}{ PGP regulations } & \multicolumn{2}{|c|}{ Disciplinary code } \\
\hline & Yes & No & Yes & No & Yes & No \\
\hline $\begin{array}{l}\text { Capixaba Foundation Institute for Accounting, Economic, and } \\
\text { Financial Research (FUCAPE)*** }\end{array}$ & $\mathrm{x}$ & & & $\mathrm{x}$ & & \\
\hline Federal University of Pernambuco (UFPE) & $\mathrm{x}$ & & & $\mathrm{x}$ & & \\
\hline Federal University of Rio de Janeiro (UFRJ) & $\mathrm{x}$ & & & $\mathrm{x}$ & & \\
\hline Federal University of Minas Gerais (UFMG) & $\mathrm{x}$ & & & $\mathrm{x}$ & & \\
\hline Federal University of Espírito Santo (UFES) & $\mathrm{x}$ & & & $x$ & & \\
\hline Federal University of Paraíba (UFPB) ${ }^{* * * *}$ & $\mathrm{x}$ & & $\mathrm{x}$ & & & \\
\hline Federal University of Goiás (UFG) & $\mathrm{x}$ & & $\mathrm{x}$ & & & \\
\hline Federal University of Uberlândia (UFU) & $\mathrm{x}$ & & $\mathrm{x}$ & & & \\
\hline Federal University of Rio Grande do Norte (UFRN) & $\mathrm{x}$ & & $\mathrm{x}$ & & & \\
\hline University of São Paulo (USP) ${ }^{* * * * *}$ & & $\mathrm{x}$ & $x$ & & & \\
\hline State University of Maringá (UEM) & & $\mathrm{x}$ & $\mathrm{x}$ & & & \\
\hline Federal University of Paraná (UFPR) & & $\mathrm{x}$ & $\mathrm{x}$ & & & \\
\hline Federal University of Bahia (UFBA) & & $\mathrm{x}$ & & $\mathrm{x}$ & & \\
\hline Federal University of Santa Catarina (UFSC) & & $\mathrm{x}$ & & $x$ & & \\
\hline Federal University of Mato Grosso do Sul (UFMS) & & $\mathrm{x}$ & & $x$ & & \\
\hline Federal University of Rio Grande (FURG) & & $\mathrm{x}$ & & $x$ & & \\
\hline Federal Rural University of Pernambuco (UFRPE) & & $\mathrm{x}$ & & $x$ & & \\
\hline
\end{tabular}

* = not located; ** = São Paulo and Ribeirão Preto; *** = Espírito Santo (Academic Master's in Management and Accounting; Academic Doctorate in Management and Accounting) and Maranhão (Master's in Management and Accounting); ${ }^{* * * *}=$ João Pessoa; ${ }^{* * * *}=$ São Paulo and Ribeirão Preto.

Source: General statute of the university, postgraduate program (PGP) regulations, and disciplinary code.

As can be observed, of the 29 institutions that offer stricto sensu postgraduate programs in accounting, 23 have some provision concerning academic dishonesty in at least one of their regulatory documents. Analyzing the regulations of the programs, only 12 have rules about the topic in their regulations or in the student disciplinary code. In other words, of the 35 programs in existence at the time of this research, only 12 had specific rules about some type of academic dishonesty.

It was observed that the penalties that were most foreseen in the general statutes of the universities were warnings, suspension, and expulsion, with a number of cases being punished with a warning alone. In the postgraduate regulations and disciplinary codes, plagiarism was the most mentioned type of academic dishonesty. In eight programs featuring information about academic dishonesty, five foresaw expulsion for engaging in plagiarism: the Federal University of Goiás (UFG), the Federal University of Rio Grande do Norte (UFRN), the Federal University of Paraíba (UFPB), USP of Ribeirão Preto, and the State University of Maringá (UEM).
According to the coordination of the program at the University of Brasilia (UnB), there are no regulations, but rather guidelines on the website of the program regarding plagiarism and falsifying data, as well as expulsion in the case of plagiarism. The Community University of the Chapecó Region (Unochapecó) has no regulations and, according to the coordination, plagiarism is addressed in the methodology disciplines and discussed with the students in all of the disciplines of the program, in which certain studies must be submitted to the ethics committee.

Differences between the students' and teachers' perceptions may occur due to a lack of clear rules at the teaching institutions and in the postgraduate programs. Nejati et al. (2011) state that disciplinary measures and strict and clear rules can help in combatting academic dishonesty. Therefore, it is important for coordinations and teaching staff to reflect on the need for this discussion in stricto sensu postgraduate programs in accounting, aligning their perceptions and attitudes to avoid academic dishonesty. 


\section{CONCLUDING REMARKS}

Considering that postgraduate programs train teachers and researchers, the partial differences found in the perceptions regarding academic dishonesty in stricto sensu postgraduate courses in accounting, in the categories of fraud/cheating, helping other students, and selfplagiarism/similarities, should be discussed, as it would be ideal for no divergences to occur. Moreover, academic dishonesty can influence the attitudes of professionals in their work environments.

With relation to the differences in students' and teachers' perceptions, these would be expected to only occur in gray cases. As the differences occurred in only one gray case, this means that academic dishonesty needs to be more widely discussed within the context of postgraduate studies. The existence of significant differences in cases of dishonesty presupposes that the groups studied find it hard to evaluate what is dishonest or not in cases of fraud/cheating and helping other students to engage in academic dishonesty.

The "expectations gap" described in the study of Braun and Stallworth (2009), such as the difference between students' and teachers' perceptions regarding academic dishonesty, exists in stricto sensu postgraduate programs in accounting. It is important to highlight that, even among the students, the perspectives of master's and doctoral students are probably different, considering the demands of master's courses, whose hourly load focused on research is not as high as in doctoral courses. As a result, perceptions regarding academic dishonesty may be different, including because of the environments the respondents are immersed in.

In addition, the existence of divergences in perceptions may indicate that the teaching institution is conducting the process for understanding and discussing academic dishonesty inefficiently. Some students probably do not clearly understand that segmenting an academic study conducted in a group lies within the realm of academic dishonesty or, also, that reusing parts of a paper previously written for another discipline, or that has already been published, can indicate self-plagiarism. If this perception is unclear to students, whether as future teachers or researchers, there exists the possibility of trivializing academic dishonesty, thus compromising the accountants' training, which requires a consolidated ethical foundation for them to carry out their role in society, as well as the development of research in the area of accounting.

Only $34.3 \%$ of the stricto sensu postgraduate programs analyzed made reference to some type of academic dishonesty. In the statutes of the universities there are provisions for academic dishonesty, but the expectation was for the regulations of the postgraduate programs to be more specific, which was not revealed in the documentary analysis. Plagiarism was the most widely found form of dishonesty in the institutional documents, as it is common in the postgraduate and research environment. However, this does not mean that the other types of academic dishonesty featuring in this study are not present in postgraduate courses, with little or no regulations on the part of the programs.

The differences identified should serve as a diagnosis for stricto sensu postgraduate programs in accounting, as the lack of detail on the types of academic dishonesty makes it hard to understand what is considered to be a dishonest behavior and the penalties they would be subject to, causing diverging decisions between teachers when they encounter dishonest behaviors on the part of students, or even leading to failure to apply such penalties.

Despite the efforts made to obtain the questionnaires back, the sample became a limitation of the research, making it impossible to generalize the results of the study for stricto sensu postgraduate programs in accounting in Brazil.

In light of the results, other studies could be undertaken in the future, such as a qualitative study to analyze the causes of there being an expectations gap in students' and teachers' perceptions regarding academically dishonest behaviors, with the aim of understanding the reasons for the differences in perceptions between the two groups. This study could be used as a basis for other research that evaluates whether students and teachers of the programs whose rules are clear in the regulations are harsher when assessing dishonest behaviors than students and teachers of the other programs. Another research possibility would be to analyze the relationship between academic dishonesty and the methodologies used by teachers in conducting their classes, and what way dishonest behaviors may be influenced by the type of methodology used. 


\section{REFERENCES}

Andrade, J. X. (2011). Má conduta na pesquisa em ciências contábeis [Tese de Doutorado]. Universidade de São Paulo. https://teses.usp.br/teses/disponiveis/12/12136/tde-10062011172859/pt-br.php

Avelino, B. C., \& Lima, G. A. S. F. de. (2017). Narcisismo e desonestidade acadêmica. Revista Universo Contábil, 13(3), 70-89. https://doi.org/10.4270/ruc.2017319

Blankenship, K. L., \& Whitley, B. E. (2000). Relation of general deviance to academic dishonesty. Ethics and Behavior, 10(1), 1-12. https://doi.org/10.1207/S15327019EB1001_1

Braun, R. L., \& Stallworth, H. L. (2009). The Academic honesty expectations gap: An analysis of accounting student and faculty perspectives. The Accounting Educators Journal, 19, 127-141.

Bueno, S. (2007). Minidicionário da língua portuguesa (2 $\left.2^{\text {nd }} \mathrm{ed}.\right)$. FTD.

Bujaki, M., Lento, C., \& Sayed, N. (2019). Utilizing professional accounting concepts to understand and respond to academic dishonesty in accounting programs. Journal of Accounting Education, 47, 28-47. https://doi.org/10.1016/j. jaccedu.2019.01.001

Coordenação de Aperfeiçoamento de Pessoal de Nível Superior (Coordination for the Improvement of Higher Education Personnel). (2019, May 10). GEOCAPES - Sistemas de informações georreferenciadas. https://geocapes.capes.gov.br/ geocapes/

Diniz, E. H. (2015). Similaridade e plagiarismo: novos desafios para a gestão de periódicos científicos. Revista de Administração de Empresas, 55(3), 239-239. https://doi. org/10.1590/S0034-759020150301

Diniz, E. H. (2018). O gato que copia: similaridades e produção acadêmica na era digital. Revista de Administração de Empresas, 58(2), 201-205. https://doi.org/10.1590/s0034759020180208

Ferreira, S. M. S. P., Kroskoscz, M., Riccio, E. L., Sakata, M., Mugnaini, R., Valente, N. Z., Dudziak. E. A., \& Fill, D. (2013). Percepções dos alunos pós-graduandos da USP sobre a ocorrência de plágio em trabalhos acadêmicos. Universidade de São Paulo. https://www.researchgate. net/publication/282877886_PERCEPCOES_DOS_ ALUNOS_POS-GRADUANDOS_DA_USP_SOBRE_A_ OCORRENCIA_DE_PLAGIO_EM_TRABALHOS_ ACADEMICOS

Frezatti, F. (2018). Déja-vu na academia: eu já vi tantas vezes esse filme! Revista de Administração de Empresas, 58(2), 206-209. https://doi.org/10.1590/s0034-759020180209

Johns, S. K.; Strand, C. A. (2000). Survey results of the ethical beliefs of business students. Journal of Education for Business, 75(6), 315-320. https://doi.org/10.1080/08832320009599034

Kisamore, J. L., Sotne, T. H., \& Jawahar, I. M. (2007). Academic integrity: The relationship between individual and situational factors on misconduct contemplations. Journal of Business Ethics, 75(4), 381-394, https://doi.org/10.1007/s10551-0069260-9
Lambert, E. G., Hogan, N. L., \& Barton, S. M. (2003). Collegiate academic dishonesty revisited: What have they done, how often have they done it, who does it, and why did they do it? Electronic Journal of Sociology, 7(4), 1-16.

McCabe, D. L. (2005). It takes a village: Academic dishonesty and educational opportunity. Liberal Education, 91(3), 26-31.

McCabe, D. L., \& Trevino, L. K. (1993). Academic dishonesty: Honor codes and other contextual influences. Journal of Higher Education, 64(5), 522-538. https://doi. org/10.2307/2959991

Murcia, F. D. (2005). Um estudo das fraudes contábeis sob duas óticas: jornais econômicos versus periódicos acadêmicos no período de 2001-2004. Revista de Contabilidade do Mestrado em Ciências Contábeis da UERJ, 10(2), 99-114. http://dx.doi. org/10.1590/S1519-70772007000300010

Nasu, V. H., \& Afonso, L. E. (2020). Relação entre cinismo e expectativa de trapaça na vida acadêmica e profissional: um estudo com alunos de cursos de pós-graduação lato sensu da área de contabilidade. Revista de Educação e Pesquisa em Contabilidade, 14(3), 352-370. https://doi.org/10.17524/repec. v14i3.2657

Nejati, M., Ismail, S., \& Shafaei. A. (2011). Students' unethical behaviour: Insights from an African country. Global Business and Management Research: An International Journal, 3(3, 4), 276-295.

Oliveira, A. C. L., Assis, A. I. R., Silva, D. M., \& Oliveira, J. D., Neto. (2014). Percepção dos discentes e docentes acerca da honestidade acadêmica em um curso de ciências contábeis. E\&G - Revista Economia e Gestão, 14(34), 86-116.

Oliveira, J. D., Neto, \& Chacarolli, O., Júnior. (2013). A visão da honestidade acadêmcia de professores e alunos de um curso superior em contabilidade. BASE - Revista de Administração e Contabilidade da Unisinos, 10(4), 324-339. https://doi. org/10.4013/base.2013.104.03

O’Neill, H. M., \& Pfeiffer, C. A. (2012). The impact of honour codes and perceptions of cheating on academic cheating behaviours, especially for MBA bound undergraduates. Accounting Education, 21(3), 231-245. https://doi.org/10.1080 /09639284.2011.590012

Pavela, G. (1997). Applying the power of association on campus: Model code of academic integrity. Journal of College and University Law, 24(1), 97-118.

Pimenta, M. A. A. (2010). Fraude em avaliações na visão de professores e estudantes: uma reflexão sobre formação profissional e ética. RPD - Revista Profissão Docente, 10(22), 124-138. https://doi.org/10.31496/rpd.v10i22.187

Sanchez, O. P., \& Innarelli, P. B. (2012). Desonestidade acadêmica, plágio e ética. $G V$-Executivo, 11(1), 46-49.

Santos, D., Cunha, J. V. A., Avelino, B. C., \& Colauto, R. D. (2020). Justiça e desonestidade acadêmica: um estudo com estudantes do curso de ciências contábeis. Revista Contemporânea de Contabilidade, 17(44), 71-86. https://doi.org/10.5007/21758069.2020v17n44p71 
Silva, O. S. F. (2008). Entre o plágio e a autoria: qual o papel da universidade? Revista Brasileira de Educação, 13(38), 357-368. https://doi.org/10.1590/S1413-24782008000200012

Simon, C. A., Carr, J. R., McCullough, S. M., Morgan, S. J., Oleson, T., \& Ressel, M. (2004). Gender, student perceptions, institutional commitments and academic dishonesty: Who reports in academic dishonesty cases? Assessment and Evaluation in Higher Education, 29(1), 75-90. https://doi. org/10.1080/0260293032000158171

Sousa. R. N., Conti, V. K., Salles, A. A., \& Mussel, I. C. R. (2016). Desonestidade acadêmica: reflexos na formação ética dos profissionais de saúde. Revista Bioética, 24(3), 459-468. https://doi.org/10.1590/1983-80422016243145

Veludo-de-Oliveira, T. M., Aguiar, F. H. O., Queiroz, J. P., \& Barrichello, A. (2014). Cola, plágio e outras práticas acadêmicas desonestas: um estudo quantitativo-descritivo sobre o comportamento de alunos de graduação e pós-graduação da área de negócios. RAM - Revista de Administração Markenzie, 15(1), 73-97. https://doi. org/10.1590/S1678-69712014000100004

Vilaça, M. M. (2018). A publicação como obsessão, a pressão como efeito e a integridade como discurso/desafio: uma análise crítico-provocativa da cientometria vigente. Motrovivência, 30(54), 51-73. http://dx.doi.org/10.5007/21758042.2018v30n54p51

Von Dran, G. M., Callahan. E. S., \& Taylor, H. V. (2001). Can students' of academic integrity be improved? Attitudes and behaviors before and after implementation of an academic integrity policy. Teaching Business Ethics, 5, 35-58. 